\section{Lifestyle-related behaviors and depressive symptoms in college students}

\section{Comportamentos relacionados ao estilo de vida e sintomas depressivos em estudantes universitários}

\section{Comportamientos relacionados con el estilo de vida y síntomas depresivos en estudiantes universitarios}

Flávia da Silva Taques Vieira 1

Ana Paula Muraro 2

Paulo Rogério Melo Rodrigues 3

Rosely Sichieri 4

Rosangela Alves Pereira 5

Márcia Gonçalves Ferreira 3

\begin{abstract}
This study sought to examine the association between lifestyle-related behaviors and depressive symptoms among college students. This cross-sectional study analyzed baseline data of a dynamic-cohort study from a public university in Central-Western Brazil, in all 21 undergraduate full-time courses. Students up to 25 years old who were enrolled for the first time in a university were included in the study, except pregnant and/or nursing women. All students who met the eligibility criteria were invited to participate in the study. From a total of 1,212 eligible students, 1,038 were included (85.6\%). All participants answered a self-administered questionnaire on smoking, alcohol consumption, screen time, sleep duration, and meal patterns. Depressive symptoms were assessed using the Patient Health Questionnaire-9 (PHQ-9). Multivariate Poisson regression models stratified by sex were used to estimate the associations. Depressive symptoms was observed in $31.6 \%$ (males 23.6\%; females 39.9\%; p-value chi-square test $=0.01)$ of the students. Smoking, drinking spirits, and having irregular meal habits were directly associated with depressive symptoms in both males and females. The co-occurrence of two risk behaviors (men: $a P R=2.23,95 \% C I$ : 1.25; 3.99; women: $a P R=1.54$, $95 \%$ CI: $1.03 ; 2.30$ ) and three or more risk behaviors (men: $a P R=3.42,95 \% C I$ : 1.90; 6.16; women: $a P R=2.09,95 \% C I: 1.39 ; 3.15)$ increased the occurrence of depressive symptoms among the students. Lifestyle-related unhealthy behaviors were associated with an increased occurrence of depressive symptoms among college students. These findings suggest the need of interventions encouraging changes in lifestyle to promote mental health and to improve the quality of life in this group.
\end{abstract}

Depressive Disorder; Students; Universities; Lifestyle; Epidemiology

\section{Correspondence}

M. G. Ferreira

Faculdade de Nutrição, Universidade Federal de Mato Grosso. Av. Fernando Corrêa da Costa 2367, Cuiabá, MT 78060-900, Brasil.

margon1101@gmail.com

1 Universidade do Estado de Mato Grosso, Cáceres, Brasil. 2 Universidade do Estado do Rio de Janeiro, Rio de Janeiro, Brasil.

3 Faculdade de Nutrição, Universidade Federal de Mato Grosso, Cuiabá, Brasil.

4 Instituto de Medicina Social, Universidade do Estado do Rio de Janeiro, Rio de Janeiro, Brasil.

5 Departamento de Nutrição Social e Aplicada, Universidade Federal do Rio de Janeiro, Rio de Janeiro, Brasil. 


\section{Introduction}

Depression is a mental disorder characterized by a loss of interest or pleasure in activities or depressed mood, accompanied by fluctuations in feelings of guilt and low self-esteem, suicidal thoughts, and other manifestations 1,2. It currently occupies the top position among the 20 most disabling diseases and affects approximately 322 million individuals, with prevalence of $4.4 \%$ worldwide ${ }^{2}$. Prevalence rates vary according to cultural differences, genetic vulnerability, environmental factors, and diagnostic tools.

Depression is common among college students with an overall estimated prevalence rate of $30.6 \%$, which varies among countries, ranging from 10 to $85 \% 3$, with a higher probability of depression in first-year students compared to later levels of undergraduate or graduate students 4 . Depression has been related to poor quality of life, unsatisfactory academic performance, university abandonment, and self-destructive behaviors 5,6.

Many conditions increase the vulnerability of college students to depression, particularly the conflicts that accompany the transition from adolescence to adulthood, pressure in academic performance, job competition, and a routine with excessive time devoted to studies 7 . Moreover, in many cases, students move away from home, and as such there is a consequent increase in independence and autonomy that requires social and affective adaptations in the face of new situations 8 .

The transition into adult life coupled with university admission may favor unhealthy changes in lifestyle, such as changes in diet quality and physical activity levels, experimentation or frequent use of cigarettes and alcoholic drinks, decreased sleep duration, decreased sun exposure, and reduced practice of outdoor activities 9,10 . These changes undermine the physiology of the brain and increase vulnerability to depression 11 .

Lifestyle-related behaviors are mostly modifiable and socially determined, and play an important role in the etiology, progression, and treatment of depression 12,13. However, a bidirectional association between lifestyle and depression is expected 13. Previous cross-sectional studies with university students have shown an association between depression and unhealthy behaviors such as smoking, alcohol consumption, physical inactivity, sleep disturbances 6,7 , and consumption of unhealthy foods 14 .

The literature consistently shows differences in prevalence rates of depression between men and women, with greater susceptibility among the latter 1,2. This includes the first Brazilian National Health Survey, conducted in 2013 15; the same pattern is observed among college students 7,16,17. Similarly, the association between depression and lifestyle-related behaviors also occurs differently for men and women 6,18,19.

Studies on depression conducted with Brazilian college students are scarce and were conducted mainly among students of health-related courses. Because the theme is relevant as a public health problem and college students are rather vulnerable to the disease, the objective of this study was to estimate the prevalence of depressive symptoms in college students and its association with lifestylerelated behaviors.

\section{Methods}

\section{Study population and data collection}

Cross-sectional study, carried out in the first academic semester of 2015 and 2016, at a public university in Central-Western Brazil. This study is part of the Longitudinal Study on the Lifestyle and Health of University Students (ELESEU). The eligibility criteria were to be enrolled in a full-time course at the studied university and to be $\leq 25$ years old. The ELESEU did not include students who had formerly attended an undergraduate course because this dynamic cohort was designed to investigate possible changes in lifestyle and health conditions related to the transition between high school and university 20 .

All students who met the eligibility criteria were invited to participate in the study.

In 2015,599 students were eligible for the study, from whom 46 (7.7\%) declined to participate and 58 (9.7\%) did not answer the questionnaire; hence, 495 college students were evaluated (82.6\% of the eligible ones). In 2016, among the eligible students ( $n=613), 28(4.6 \%)$ refused to participate in the 
study and 42 (6.9\%) did not answer the questionnaire; thus, 543 students were evaluated. Therefore, a total of 1,038 participants were included in this analysis, representing $85.6 \%$ of the eligible students in both years.

Data were collected by trained interviewers who followed standardized procedures and used a structured, self-administered questionnaire containing demographic, socioeconomic and lifestylerelated information, as well as questions about depressive symptoms. Further details on the methodology of the ELESEU study are available elsewhere 20.

\section{Outcome}

The presence of depressive symptoms was evaluated using the Patient Health Questionnaire-9 (PHQ9) validated for the Brazilian population with high sensitivity and specificity 21 . The nine-question scores were assessed on a Likert scale, ranging from 0 to 3, corresponding to the options "not at all (0)", "several days (1)", "more than half the days (2)", and "nearly every day (3)". The scores of the questions were summed and the cut-off point $\geq 9$ was used as a criterion to identify the presence of depressive symptoms.

\section{Measurements}

Lifestyle-related behaviors were defined as follows: elevated screen time 22 , including television, computers, and video games, was defined with the cut-off point based on the 75 th percentile of the participants' screen time distribution ( $\leq 4$ hours or $>4$ hours); smoking (current smoker, non-smoker, mild smoker: 1 to 10 cigarettes daily, or moderate to heavy smoker: 11 to 20 cigarettes daily) 23,24; type of alcoholic beverage consumed (none, beer, wine, or spirits); sleep duration ( $\geq 6$ hours or $<6$ hours daily) 18; meal patterns (satisfactory: at least breakfast, lunch and dinner daily; or irregular: one or two main meals daily) 25 . Additionally, students were classified according to the co-occurrence of lifestyle-related behaviors (none, 1 behavior, 2 behaviors or $\geq 3$ behaviors).

Age group (16-17; 18-19; $\geq 20$ years old), economic level, field of study, and body mass index (BMI) were the variables used in the adjustment of the final model. The economic level of the families was evaluated using the criteria established by the Brazilian Association of Research Companies (http:// www.abep.org/criterio-brasil, accessed on 22/Nov/2017), in 2015, which employs a scoring system from A (highest) to E (lowest) based on household appliances, owned cars, having domestic servants at home, and schooling level of the head of the family. BMI $\left(\mathrm{kg} / \mathrm{m}^{2}\right)$ was calculated with a basis on measured weight and height according to standardized techniques 26 . Weight status was categorized using the BMI according to criteria recommended by the World Health Organization (WHO) for adults 27 and adolescents 28 .

The knowledge area of the undergraduate courses was categorized according to Brazilian Ministry of Education classification into five main fields (http://www.capes.gov.br/avaliacao/instrumentosde-apoio/tabela-de-areas-do-conhecimento-avaliacao, accessed on 30/Nov/2017): (1) Agricultural Sciences: agronomy, forestry, animal husbandry, veterinary medicine; (2) Engineering: civil, electrical, sanitary; (3) Exact and Earth Sciences: mathematics, computer science, physics, chemistry, geology; (4) Life and Health Sciences: biology, medicine, nutrition, nursing; (5) Social and Human Sciences: architecture, urbanism, philosophy, psychology.

\section{Statistical analysis}

Statistical analyses were performed using SPSS software, version 17.0 (https://www.ibm.com/). All the analyses were stratified according to sex. The chi-square test was applied to evaluate the association between the independent variables and the presence of depressive symptoms. Poisson regression models with robust variance were used to estimate the crude (PR) and adjusted (aPR) prevalence ratio and their respective $95 \%$ confidence intervals (95\%CI). The covariates that presented a p-value $\leq 0.20$ in the bivariate analysis were selected for adjustments in the final multiple models. Separate models were constructed for each lifestyle-related behavior, adjusted for age, economic level, undergraduate 
course field of knowledge, and BMI. In addition, alcohol consumption and smoking were mutually adjusted. Each model's fit was evaluated using deviance statistic.

\section{Ethical issues}

The research project was approved by the Research Ethics Committee of the Júlio Muller University Hospital of the Federal University of Mato Grosso (n. 1.006.048, March 31, 2015). The participants were informed about the purposes of the study and data was collected only after they had signed the Free and Informed Consent Form.

\section{Results}

A total of 1,038 college students were evaluated: $51 \%$ were men, $47.4 \%$ belonged to economic level B, 59.4\% were between 17 and 19 years old and 31.6\% reported depression symptoms, being 39.9\% among women and $23.6 \%$ in men $(\mathrm{p}=0.01)$. Due to the differences between men and women in the prevalence of depressive symptoms, the statistical analyses were stratified by sex.

Demographic and socioeconomic variables did not present significant association with depressive symptoms in either sex. There was a statistically significant difference in the prevalence of the outcome according to the field of knowledge of the undergraduate course $(\mathrm{p}<0.01)$. Among men, the highest prevalence of depressive symptoms was found among students of the Social and Human Sciences field (48.6\%) while among women, the highest depressive symptoms prevalence was observed among students of Exact and Earth Sciences courses (52.3\%) and among students of the Social and Human Sciences (48.8\%), with no difference in the prevalence of depressive symptoms among women in these two fields of knowledge (Table 1).

For men, in the adjusted model, the prevalence of depressive symptoms was higher among those reporting more than 4 hours per day of screen time ( $\mathrm{aPR}=1.61,95 \% \mathrm{CI}: 1.18 ; 2.20)$, smokers (mild: $\mathrm{aPR}=1.73$, 95\%CI: $1.08 ; 2.77$; moderate to heavy: $\mathrm{aPR}=2.51,95 \% \mathrm{CI}: 1.47,4.29)$, who consumed beverages with a higher alcohol content (spirits: $\mathrm{aPR}=1.45,95 \% \mathrm{CI}: 1.01 ; 2.08$ ), and those reporting irregular meal patterns ( $\mathrm{aPR}=1.77,95 \% \mathrm{CI}$ : $1.26 ; 2.48$ ), compared to those who did not present any of the mentioned behaviors. Sleep duration was not associated with depressive symptoms among men (Table 2). It was observed among men an association between the co-occurrence of two lifestylerelated behaviors $(\mathrm{aPR}=2.23,95 \% \mathrm{CI}: 1.25,3.99)$ and three or more lifestyle-related behaviors $(\mathrm{aPR}=$ 3.42, 95\%CI: 1.90; 6.16) with depressive symptoms (Table 3).

Regarding the women, after adjusting for confounding factors, there was higher prevalence of depressive symptoms among moderate to heavy smokers ( $\mathrm{PPR}=2.44,95 \% \mathrm{CI}$ : $1.56 ; 3.82)$ compared to nonsmokers and those that consumed spirits ( $\mathrm{aPR}=1.42,95 \% \mathrm{CI}: 1.12 ; 1.81$ ) compared to nondrinkers. There was also higher prevalence of the outcome among students who presented irregular meal patterns $(\mathrm{aPR}=1.35$, 95\%CI: $1.04 ; 1.73)$ compared to those with satisfactory meal patterns and those who reported sleeping less than 6 hours per day $(\mathrm{aPR}=1.40,95 \% \mathrm{CI}: 1.11 ; 1.77)$ compared to those reporting to sleep $\geq 6$ hours per day. Sedentary behaviors were not associated with depressive symptoms among women (Table 2). The prevalence of depressive symptoms was higher among female college students who presented co-occurrence of two lifestyle-related behaviors $(\mathrm{aPR}=1.54,95 \% \mathrm{CI}$ : $1.03 ; 2.30)$ and three or more lifestyle-related behaviors ( $\mathrm{PPR}=2.09,95 \% \mathrm{CI}: 1.39 ; 3.15)$ (Table 3). 
Table 1

Distribution of the participants (\%) and prevalence (P) of depressive symptoms by sex according to sociodemographic and economic variables, field of study, and weight status of college students evaluated in the baseline of the Longitudinal Study on the Lifestyle and Health of University Students (ELESEU). Cuiabá, Mato Grosso State, Brazil, 2015-2016.

\begin{tabular}{|c|c|c|c|c|c|c|c|c|}
\hline \multirow[t]{2}{*}{ Characteristics } & \multicolumn{4}{|c|}{ Males } & \multicolumn{4}{|c|}{ Females } \\
\hline & $\mathbf{n}$ & $\%$ & $\mathbf{P}$ & p-value * & $\mathbf{n}$ & $\%$ & $\mathbf{P}$ & p-value * \\
\hline Total & 529 & 51 & 23.6 & & 509 & 49 & 39.9 & 0.01 \\
\hline \multicolumn{9}{|l|}{ Age group (years) } \\
\hline $16-17$ & 99 & 18.7 & 18.2 & 0.18 & 102 & 20.0 & 33.3 & 0.28 \\
\hline $18-19$ & 312 & 59.0 & 23.4 & & 305 & 59.9 & 42.3 & \\
\hline$\geq 20$ & 118 & 22.3 & 28.8 & & 102 & 20.0 & 39.2 & \\
\hline \multicolumn{9}{|l|}{ Economic level $* \star, \star \star *$} \\
\hline A & 93 & 17.7 & 19.4 & 0.22 & 102 & 20.0 & 42.2 & 0.18 \\
\hline B & 255 & 48.5 & 21.6 & & 248 & 48.7 & 37.1 & \\
\hline C & 167 & 31.7 & 28.1 & & 149 & 29.3 & 40.9 & \\
\hline$D-E$ & 11 & 2.1 & 36.4 & & 10 & 2.0 & 70.0 & \\
\hline \multicolumn{9}{|l|}{ Living situation } \\
\hline Alone & 93 & 17.6 & 29.0 & 0.37 & 67 & 13.2 & 40.3 & 0.89 \\
\hline With parents or relatives & 362 & 68.4 & 22.1 & & 359 & 70.5 & 39.3 & \\
\hline With others & 74 & 14.0 & 24.3 & & 83 & 16.3 & 42.2 & \\
\hline \multicolumn{9}{|l|}{ Field of study \# } \\
\hline Agricultural Sciences & 111 & 21.0 & 17.1 & $<0.01$ & 104 & 20.4 & 30.8 & $<0.01$ \\
\hline Engineering & 141 & 26.7 & 21.3 & & 63 & 12.4 & 38.1 & \\
\hline Exact and Earth Sciences & 176 & 33.3 & 22.2 & & 109 & 21.4 & 52.3 & \\
\hline Life and Health Sciences & 66 & 12.5 & 30.3 & & 151 & 29.7 & 33.1 & \\
\hline Social and Human Sciences & 35 & 6.6 & 48.6 & & 82 & 16.1 & 48.8 & \\
\hline \multicolumn{9}{|l|}{ Weight status \#\# } \\
\hline Underweight & 22 & 4.2 & 22.7 & 0.14 & 22 & 4.3 & 27.3 & 0.05 \\
\hline Normal weight & 366 & 69.2 & 21.0 & & 384 & 75.6 & 37.8 & \\
\hline Overweight & 97 & 18.3 & 28.9 & & 75 & 14.8 & 53.3 & \\
\hline Obesity & 44 & 8.3 & 34.1 & & 27 & 5.3 & 44.4 & \\
\hline
\end{tabular}

* p-value associated with the chi-square test;

** Three missing cases among males;

*** According to the Brazilian Association of Research Companies (http://www.abep.org/criterio-brasil, accessed on 22/ Nov/2017);

\# Bonferroni correction: males - proportion of depressive symptoms greater in students of Social and Human Sciences courses than in any other category $(p<0.05)$, excepted among students of Life and Health Sciences $(p=0.72)$; females proportion of depressive symptoms greater in students of Exact and Earth Sciences courses compared to those of Life and Health Sciences courses $(p=0.02)$ and those of Agricultural Sciences courses $(p=0.01)$;

\#\# According to the World Health Organization 27,28. 


\section{Table 2}

Distribution of the participants (\%), prevalence (P) of depressive symptoms, crude (PR) and adjusted (aPR) prevalence ratio and respective $95 \%$ confidence intervals $(95 \% \mathrm{Cl})$ according to sex and lifestyle-related behaviors variables among college students evaluated in the baseline of the Longitudinal Study on the Lifestyle and Health of University Students (ELESEU). Cuiabá, Mato Grosso State, Brazil, 2015-2016.

\begin{tabular}{|c|c|c|c|c|c|c|c|c|}
\hline \multirow[t]{2}{*}{ Characteristics } & \multicolumn{4}{|c|}{ Males $(n=529)$} & \multicolumn{4}{|c|}{ Females $(n=509)$} \\
\hline & $\%$ & $\mathbf{P}$ & PR $(95 \% \mathrm{Cl})$ & $\mathrm{aPR} *(95 \% \mathrm{Cl})$ & $\%$ & $\mathbf{P}$ & PR $(95 \% \mathrm{Cl})$ & $\mathrm{aPR} *(95 \% \mathrm{Cl})$ \\
\hline \multicolumn{9}{|c|}{ Sedentary behaviors (hours/day) ** } \\
\hline$\leq 4$ & 76.2 & 20.3 & 1.00 & 1.00 & 80.0 & 38.8 & 1.00 & 1.00 \\
\hline$>4$ & 23.8 & 34.1 & $1.68(1.23 ; 2.29)$ & $1.61(1.18 ; 2.20)$ & 20.0 & 44.1 & $1.14(0.89 ; 1.46)$ & $1.12(0.87 ; 1.43)$ \\
\hline \multicolumn{9}{|l|}{ Smoking ** } \\
\hline No & 93.2 & 21.9 & 1.00 & 1.00 & 94.3 & 38.5 & 1.00 & 1.00 \\
\hline Mild & 5.9 & 41.9 & $1.91(1.23 ; 2.99)$ & $1.73(1.08 ; 2.77) * \star \star$ & 5.5 & 60.7 & $1.58(1.14 ; 2.17)$ & $1.32(0.97 ; 1.79) * * *$ \\
\hline Moderate to heavy & 0.9 & 80.0 & $3.65(2.29 ; 5.84)$ & $2.51(1.47 ; 4.29) * \star *$ & 0.2 & 100.0 & $2.60(2.32 ; 2.91)$ & $2.44(1.56 ; 3.82) * * *$ \\
\hline \multicolumn{9}{|c|}{ Type of alcoholic beverage ** } \\
\hline None & 58.4 & 21.7 & 1.00 & 1.00 & 62.9 & 36.6 & 1.00 & 1.00 \\
\hline Beer & 18.7 & 19.2 & $0.89(0.56 ; 1.40)$ & $0.92(0.59 ; 1,44) \#$ & 14.3 & 38.4 & $1.05(0.76 ; 1.45)$ & $1.02(0.74 ; 1.41) \#$ \\
\hline Wine & 4.5 & 37.5 & $1.73(0.99 ; 3.02)$ & $1.49(0.79 ; 2.82) \#$ & 5.5 & 42.9 & $1.17(0.75 ; 1.84)$ & $1.09(0.71 ; 1.67) \#$ \\
\hline Spirits & 18.3 & 30.9 & $1.43(0.99 ; 2.06)$ & $1.45(1.01 ; 2.08) \#$ & 17.3 & 52.3 & $1.43(1.12 ; 1.83)$ & $1.42(1.12 ; 1.81) \#$ \\
\hline \multicolumn{9}{|c|}{ Sleep duration (hours/day) ** } \\
\hline$\geq 6$ & 82.6 & 22.0 & 1.00 & 1.00 & 79.5 & 37.4 & 1.00 & 1.00 \\
\hline$<6$ & 17.4 & 31.5 & $1.45(1.02 ; 2.05)$ & $1.37(0.96 ; 1.97)$ & 20.5 & 50.0 & $1.33(1.05 ; 1.67)$ & $1.40(1.11 ; 1.77)$ \\
\hline \multicolumn{9}{|l|}{ Meal patterns ** } \\
\hline Satisfactory & 43.3 & 16.6 & 1.00 & 1.00 & 31.0 & 31.6 & 1.00 & 1.00 \\
\hline Irregular & 56.7 & 29.0 & $1.75(1.24 ; 2.46)$ & $1.77(1.26 ; 2.48)$ & 69.0 & 43.6 & $1.38(1.06 ; 1.78)$ & $1.35(1.04 ; 1.73)$ \\
\hline
\end{tabular}

* Models adjusted for age, economic level, field of study, and body mass index;

** Adequacy of the model verified by the statistical deviance $(p>0.05)$ for all models;

*** Additional adjustment by type of alcoholic beverage consumed;

\# Additional adjustment by the number of cigarettes smoked per day.

Table 3

Distribution of the participants (\%), prevalence (P) of depressive symptoms, crude (PR) and adjusted (aPR) prevalence ratio and respective $95 \%$ confidence intervals $(95 \% \mathrm{Cl})$ by sex according to the co-occurrence of risk behaviors among college students evaluated in the baseline of the Longitudinal Study on the Lifestyle and Health of University Students (ELESEU). Cuiabá, Mato Grosso State, Brazil, 2015-2016.

\begin{tabular}{|c|c|c|c|c|c|c|c|c|}
\hline \multirow[t]{2}{*}{ Co-occurrence of risk behaviors *,** } & \multicolumn{4}{|c|}{ Males $(n=529)$} & \multicolumn{4}{|c|}{ Females $(n=509)$} \\
\hline & $\%$ & $\mathbf{P}$ & PR $(95 \% \mathrm{Cl})$ & aPR *** $(95 \% \mathrm{Cl})$ & $\%$ & $\mathbf{P}$ & PR $(95 \% \mathrm{Cl})$ & aPR *** $(95 \% \mathrm{Cl})$ \\
\hline None & 18.3 & 12.4 & 1.00 & 1.00 & 15.4 & 26,9 & 1.00 & 1.00 \\
\hline 1 behavior & 36.1 & 18.8 & $1.52(0.83 ; 2.79)$ & $1.62(0.89 ; 2.96)$ & 35.2 & 35.8 & $1.33(0.88 ; 2.01)$ & $1.30(0.86 ; 1.97)$ \\
\hline 2 behaviors & 31.0 & 26.8 & $2.17(1.21 ; 3.90)$ & $2.23(1.25 ; 3.99)$ & 34.3 & 42.0 & $1.56(1.04 ; 2.34)$ & $1.54(1.03 ; 2.30)$ \\
\hline$\geq 3$ behaviors & 14.6 & 42.9 & $3.46(1.92 ; 6.24)$ & $3.42(1.90 ; 6.16)$ & 15.2 & 58.4 & $2.17(1.44 ; 3.28)$ & $2.09(1.39 ; 3.15)$ \\
\hline
\end{tabular}

* Five risk behaviors were evaluated: sedentary behaviors $>4$ hours/day, smoking (at least 1 cigarette/day), alcohol consumption, sleep duration $<6$ hours/day and irregular meal pattern;

** Adequacy of the model verified by the statistical deviance $(p>0.05)$;

*** Models adjusted for age, economic level, field of study, and body mass index. 


\section{Discussion}

A census study with Brazilian college students enrolled in full-time courses showed that almost one third of them presented depressive symptoms, with higher prevalence in females; moreover, the association between unhealthy behaviors and depressive symptoms presented differences according to sex. Sleep duration was only associated with depressive symptoms among females while screen time, only among males. In addition, smoking, type of alcoholic beverage consumed, irregular meal patterns, and the co-occurrence of unhealthy lifestyle-related behaviors were associated with depressive symptoms in both sexes.

The prevalence of depressive symptoms among college students observed in this study was similar to the figures found in a systematic review ${ }^{3}$ and also in cross-sectional studies conducted with college students from several countries, using different detection methods 6,7,19. However, a cross-sectional study conducted in the United States, between 2007 and 2013, using the PHQ-9 instrument and including 61,561 college students, estimated a prevalence of depressive symptoms of $24.1 \% 29$, hence, below to the $31.6 \%$ estimated in our study. The high figures estimated for prevalence of depressive symptoms in our study is partially due to the cut-off of 9 points, a cutoff acceptable to associate depressive symptoms with other factors 21 .

In our study, in both sexes, compared to other fields of study, high prevalence of depressive symptoms was observed among students of Social and Human Sciences. Similar studies carried out in Brazil found that students from Life and Health Sciences 30 , especially in medical schools 31,32, presented higher prevalence of depressive symptoms compared to students from other fields of knowledge. According to Brandtner \& Bardagi 33, students of human sciences are more concerned with the interpersonal relationships, which may favor greater sensitivity to emotional issues and would justify the higher prevalence of depressive symptoms in this group. In this study, a high prevalence of depressive symptoms was also observed among women of the Exact and Earth Sciences courses. This particularity may be related to discriminatory attitudes towards women in this field of knowledge, which creates perspectives of unequal opportunities in the labor market, due to the stigmas of these fields of knowledge seen as typically masculine 34 .

Longitudinal studies $35,36,37$ and a systematic review 13 have shown a bidirectional relationship between lifestyle-related behaviors and depression, suggesting that unhealthy behaviors may favor the occurrence of depressive disorders, and the presence of these disorders may have an impact on these behaviors. This relationship is also justified by a series of neurobiological processes that are influenced by lifestyle as well as by the physiological pathways of major depression, thus forming a cycle 38 .

In this study, college students with lifestyle-related risk behaviors had higher prevalence of depressive symptoms compared to those with healthier behaviors. Studies with college students have related depression to alcohol abuse or dependence 5,6,39. The results found in our study showed an association of depressive symptoms with the consumption of beverages with higher alcohol content in both sexes, even though alcohol consumption had not been characterized as abusive or had been found to be addictive. There are studies showing that disorders relative to alcohol consumption increase the risk of major depression in young adults 40 while for college students major depression increases the risk of alcohol abuse or dependence ${ }^{39}$. Different theories have suggested that excessive or abusive consumption of alcohol can cause depression in a short period of time as a result of the pharmacological effects of alcohol in adult men 41.

Only among the studied male students there was a direct association between sedentary behaviors with depressive symptoms. In our study, evaluation of sedentary behaviors was based on screen time, including television, computers, and video games. The time using electronic devices has been associated with depression in college students, which was directly associated with problematic cell phone use 42 , and with screen time above two hours per day 22,43. However, a study with Chinese college students has shown an inverse association between screen time of up to two hours daily and depression 44. In addition, a prospective study showed that the chance of depression at the baseline was $55 \%$ higher for college students exposed to the longer screen time ( $>2$ hours/day), compared to those with shorter screen time ( $\leq 2$ hours/day), and after one year of follow-up, the chance of depression among participants with the longest exposure time was $92 \%$ higher 37 . Similarly, a longitudinal study carried out in Bangladesh found higher risk of depression among college students exposed to $\geq 4$ hours per 
day of screen time when compared to those with $<2$ hours per day of screen time 22 . Comparable results were found in a systematic review confirming the association between sedentary behaviors such as watching television or using the computer and a higher risk of depression in adults 45 .

In this study, smoking was directly associated with depressive symptoms in both male and female college students, and the prevalence of depressive symptoms among those who smoked more than ten cigarettes per day was over twice than that observed for individuals who reported that they did not smoke. Similar results were observed in cross-sectional studies with college students 46,47 . In a cohort study conducted in Denmark with participants aged over 20 years, followed for 26 years, smoking was associated with an increased risk of developing depression 36.

Some hypotheses are considered in the literature for the association between depression and smoking, either as a mechanism to alleviate negative feelings or because it provides pleasure and socialization 47 . However, in the reverse direction, the effect of nicotine on neurotransmitter activity in the brain can cause changes that increase the risk of depression 48 . Tobacco use is more common among women as a strategy to reduce negative feelings, relieve symptoms of bad moods, and loss of pleasure 19 .

This study showed higher prevalence of depressive symptoms among students of both sexes with irregular meal patterns, compared to those having satisfactory meal patterns. Cross-sectional studies have shown consistency in the association between depression among college students and irregular meals and meal skipping 7,8,14,49. The benefits of regularly having breakfast, for example, have been discussed in recent research and the findings have shown that having breakfast is associated with lower scores of depression among university students 7 and that skipping breakfast significantly increases the risks of stress and depressive mood in adolescents older than 16 years 49 .

In this study, sleep duration under six hours daily showed a significant association with depressive symptoms among females. Even after further adjustments, sleep time fewer than six hours daily represented a $40 \%$ increase in the prevalence of depressive symptoms. These findings are comparable to cross-sectional population-based studies which have suggested that the reduction of only one hour of sleep over the recommended amount can cause significant damage, and it is associated with depression 18,50. Among college students, sleep time fewer than six hours daily increases the likelihood of depression by $79 \%$ compared to students who sleep for more than six hours 7 . In adolescents, sleep deprivation may lead to an increase in negative mood and a decrease in the ability to regulate emotions 51 . In students aged over 18 years, sleep disturbances may lead to cognitive and mood changes 52 .

The co-occurrence of lifestyle-related risk behaviors among college students and their association with depressive symptoms were evaluated in this study. The prevalence of depressive symptoms increased with the number of aggregated unhealthy behaviors among males as well as among females. Similarly, a study carried out with 2,422 Chinese university students found that participants with two or more risk behaviors (physical inactivity, sleep disturbances, poor eating behavior, Internet addiction disorder, frequent alcohol use, smoking) presented higher prevalence of depressive symptoms when compared to those with less than two risk behaviors 53 .

The identification of depressive symptoms based on self-reports may be considered a limitation of the study, because of the possibility of information bias. Nevertheless, the instrument used in this study, the PHQ-9, was validated for the Brazilian population and was applied in the most important nationwide health survey conducted in Brazil 54. In addition, the prevalence of depressive symptoms found among college students is consistent with findings from other studies in this population group in several countries 3,6,7,19.

Another limitation of this study was the lack of information on physical activity. The practice of physical activity may be a protective factor against depression. A four-year follow-up study in Germany showed that regular physical activity practitioners between 14-24 years old had lower incidence of depressive disorders, including major depressive disorder, compared with those who did not practice physical activity 55. On the other hand, physical inactivity may be related to some symptoms of depression such as lack of energy or apathy 56. A systematic review of controlled trials has shown that exercise reduces depressive symptoms in people aged over 18 years with a diagnosis of depression 57 . Previous studies with college students have shown that the practice of physical activity promotes greater personal fulfillment, reduces exhaustion and, consequently, improves emotional well-being, thus relieving the depressive mood 58,59. 
This study also has strengths. First of all, the group examined was selected from a census and involved students from various fields of knowledge; since in similar studies conducted in Brazil the prevalence of depression and associated factors was evaluated in students from specific areas, particularly from medical schools 31,32 . Furthermore, in this study, the association between various lifestylerelated behaviors and depressive symptoms was analyzed, which was an advantage if compared to analogous studies that usually focused on specific risk factors $14,19,29,39,46,47,50$. It is noteworthy that this study's findings on the association of lifestyle-related behaviors with depressive symptoms among college students are consistent with longitudinal studies 22,37,48,49,60, as well as systematic reviews $3,13,61$ and a meta-analysis 62 .

In addition, the study analyzed $85.6 \%$ of the eligible population, using procedures widely tested in epidemiological studies and robust statistical analysis with control of potential confounding factors, characteristics that support the consistency of the results found and the internal validity of the study. There were also no differences between students who participated in the study and those that did not participate according to sex and course ( $p>0.05$, data not shown).

In face of the high prevalence of depressive symptoms among college students, universities, as environments aimed at developing citizenship, should be committed to implementing initiatives and policies that favor students' health. The promotion of mental health among college students should be prioritized by the development of activities that stimulate positive changes in lifestyle, by early detection of mental disorders, especially depressive symptoms, and by putting into service programs to support students with psychological problems, which is provided by the university where this study was carried out. Such proposals may reduce the burden of mental disorders, help to ensure a successful academic performance, and to improve the quality of life of this population group.

In conclusion, there was a high prevalence of depressive symptoms among the university students evaluated in this study, especially among women. Lifestyle-related behaviors were associated with depressive symptoms differently for men and women. Participants with unfavorable behaviors had higher prevalence of depression-related symptoms and the co-occurrence of unhealthy lifestylerelated increased the prevalence of the depressive symptoms in this population.

\section{Contributors}

F. S. T. Vieira contributed to the data collection, statistical analysis, interpretation of the results, and writing. A. P. Muraro and M. G. Ferreira contributed to the article concept and design, statistical analysis, interpretation of results, writing, and critical revision of the manuscript. P. R. M. Rodrigues, $\mathrm{R}$. Sichieri, and R. A. Pereira contributed to the article design, interpretation of data, and critical revision of the manuscript.

\section{Additional informations}

ORCID: Flávia da Silva Taques Vieira (0000-00018837-9059); Ana Paula Muraro (0000-0001-62371673); Paulo Rogério Melo Rodrigues (0000-00024213-0685); Rosely Sichieri (0000-0001-52865354); Rosangela Alves Pereira (0000-0002-98869796); Márcia Gonçalves Ferreira (0000-00018362-0819).

\section{Acknowledgments}

The authors appreciate the collaboration from the students who kindly agreed to participate in the study. 


\section{References}

1. American Psychiatric Association. Manual de transtornos mentais DSM-5. 5a Ed. Porto Alegre: Artmed; 2014.

2. World Health Organization. Depression and other common mental disorders: global health estimates. Geneva: World Health Organization; 2017.

3. Ibrahim AK, Kelly SJ, Adams CE, Glazebrook C. A systematic review of studies of depression prevalence in university students. J Psychiatr Res 2013; 47:391-400.

4. Farrer LM, Gulliver A, Bennet K, Fassnacht DB, Griffiths KM. Demographic and psychosocial predictors of major depression and generalised anxiety disorder in Australian university students. BMC Psychiatry 2016; 16:241.

5. Buchanan JL. Prevention of depression in the college student population: a review of the literature. Arch Psychiatr Nurs 2012; 26:21-42.

6. Mohammed H, Hayati KS, Salmiah MS. Coping with depression, anxiety, and stress: a cross-sectional study among Malaysian students in a public university. IOSR Journal of Dental and Medical Sciences 2016; 15:83-95.

7. Xu Y, Qi J, Wen X, Yang Y. The contribution of lifestyle factors to depressive symptoms: a cross-sectional study in Chinese college students. Psychiatry Res 2016; 245:243-9.

8. Lovell GP, Nash K, Sharman R, Lane BR. A cross-sectional investigation of depressive, anxiety, and stress symptoms and health-behavior participation in Australian university students. Nurs Health Sci 2015; 17:134-42.

9. Butler SM, Black DR, Carolyn Blue FL, Gretebeck RJ. Change in diet, physical activity, and body weight in female college freshman. Am J Health Behav 2004; 28:24-32.

10. Wengreen HJ, Moncur C. Change in diet, physical activity, and body weight among young-adults during the transition from high school to college. Nutr J 2009; 8:32.

11. Sarbadhikari SN, Saha AK. Moderate exercise and chronic stress produce counteractive effects on different areas of the brain by acting through various neurotransmitter receptor subtypes: a hypothesis. Theor Biol Med Model 2006; 3:33.

12. García-Toro M, Ibarra O, Gili M, Serrano MJ, Vives M, Monzón S, et al. Adherence to lifestyle recommendations by patients with depression. Rev Psiquiatr Salud Ment 2012; 5:236-40

13. Lopresti AL, Hood SD, Drummond PD. A review of lifestyle factors that contribute to important pathways associated with major depression: diet, sleep and exercise. J Affect Disord 2013; 148:12-27.

14. Lazarevich I, Irigoyen-Camacho ME, Velázquez-Alva MC. Obesidad, conducta alimentaria y salud mental en estudiantes universitarios de la Ciudad de México. Nutr Hosp 2013; 28:1892-9.
15. Lopes CS, Hellwig N, Azevedo e Silva G Menezes PR. Inequities in access to depression treatment: results of the Brazilian National Health Survey - PNS. Int J Equity Health 2016; 15:154

16. Eisenberg D, Hunt J, Speer N. Mental health in American colleges and universities. J Nerv Ment Dis 2013; 201:60-7.

17. Reyes-Rodríguez ML, Rivera-Medina CL, Cámara-Fuentes L, Suárez-Torres A, Bernal G. Depression symptoms and stressful life events among college students in Puerto Rico. J Affect Disord 2013; 145:324-30.

18. Lee M-S, Shin J-S, Lee J, Lee YJ, Kim M, Park $\mathrm{KB}$, et al. The association between mental health, chronic disease and sleep duration in Koreans: a cross-sectional study. BMC Public Health 2015; 15:1200.

19. Morrell HER, Cohen LM, McChargue DE. Depression vulnerability predicts cigarette smoking among college students: gender and negative reinforcement expectancies as contributing factors. Addict Behav 2010; 35:607-11.

20. Nogueira PS, Ferreira MG, Rodrigues PRM, Muraro AP, Pereira LP, Pereira RA. Longitudinal Study on Lifestyle and Health of University Students (ELESEU): design, methodological procedures and preliminary results. Cad Saúde Pública 2018; 34:e00145917.

21. Santos IS, Tavares BF, Munhoz TN, Almeida LSP, Silva NTB, Tams BD, et al. Sensibilidade e especificidade do Patient Health Questionnaire-9 (PHQ-9) entre adultos da população geral. Cad Saúde Pública 2013; 29:1533-43.

22. Hossain S, Anjum A, Uddin ME, Rahman MA, Hossain MF. Impacts of socio-cultural environment and lifestyle factors on the psychological health of university students in Bangladesh: a longitudinal study. J Affect Disord 2019; 256:393-403.

23. Chkhaidze I, Maglakelidze N, Maglakelidze T, Khaltaev N. Prevalência de tabagismo e fatores que o influenciam em estudantes de medicina e outros universitários em Tbilisi, Geórgia. J Bras Pneumol 2013; 31:523-7.

24. Heatherton TF, Kozlowski LT, Frecker RC, Fagerstrom KO. The Fagerstrom Test for Nicotine Dependence: a revision of the Fagerström Tolerance Questionnaire. Br J Addict 1991; 86:1119-27.

25. Rodrigues PRM, Padez CMP, Ferreira MG, Gonçalves-Silva RMV, Pereira RA. Multiple risk behaviors for non-communicable diseases and associated factors in adolescents. Rev Nutr 2016; 29:185-97.

26. Gordon C, Chumlea W, Roche A. Stature, recumbent length and weight. In: Lohman TG, Roche AF, Martorell R, editors. Anthropometric standardization reference manual. Champaign: Human Kinetics; 1988. p. 3-8. 
27. World Health Organization. Physical status: the use and interpretation of anthropometry. Geneva: World Health Organization; 1995. (WHO Technical Report Series, 854).

28. World Health Organization. Growth reference data for 5-19 years: body mass index-for-age, length/height-for-age and weight-for-height. WHO Reference 2007. http://www.who.int/ growthref/en/ (accessed on 04/Jun/2010).

29. Pedrelli P, Borsari B, Lipson SK, Heinze JE, Eisenberg D. Gender differences in the relationships among major depressive disorder, heavy alcohol use, and mental health treatment engagement among college students. J Stud Alcohol Drugs 2016; 77:620-8.

30. Sakae TM, Padão DL, Jornada LK. Sintomas depressivos em estudantes da área da saúde em uma universidade no sul de Santa Catarina UNISUL. Rev AMRIGS 2010; 54:38-43.

31. Mayer FB, Santos IS, Silveira PSP, Lopes MHI, Souza ARND, Campos EP, et al. Factors associated to depression and anxiety in medical students: a multicenter study. BMC Med Educ 2016; 16:282.

32. Pacheco JPG, Giacomin HT, Tam WW, Ribeiro TB, Arab C, Bezerra IM, et al. Mental health problems among medical students in Brazil: a systematic review and meta-analysis. Rev Bras Psiquiatr 2017; 39:369-78.

33. Brandtner M, Bardagi M. Sintomatologia de depressão e ansiedade em estudantes de uma universidade privada do Rio Grande do Sul. Gerais (Univ. Fed. Juiz Fora) 2009; 2:81-91.

34. Vasconcellos ECC, Brisolla SN. Presença feminina no estudo e no trabalho da ciência na Unicamp. Cadernos Pagu 2009; (32):215-65.

35. Da Silva MA, Singh-Manoux A, Brunner EJ, Kaffashian S, Shipley MJ, Kivimäki M, et al. Bidirectional association between physical activity and symptoms of anxiety and depression: The Whitehall II Study. Eur J Epidemiol 2012; 27:537-46

36. Flensborg-Madsen T, von Scholten MB, Flachs EM, Mortensen EL, Prescott E, Tolstrup JS. Tobacco smoking as a risk factor for depression. A 26-year population-based follow-up study. J Psychiatr Res 2011; 45:143-9.

37. Wu X, Tao S, Zhang S, Zhang Y, Chen K, Yang $\mathrm{Y}$, et al. Impact of screen time on mental health problems progression in youth: a 1 -year follow-up study. BMJ Open 2016; 6:e011533.

38. Leonard B, Maes M. Mechanistic explanations how cell-mediated immune activation, inflammation and oxidative and nitrosative stress pathways and their sequels and concomitants play a role in the pathophysiology of unipolar depression. Neurosci Biobehav Rev 2012; 36:764-85.

39. Kuo P-H, Gardner Jr. CO, Kendler KS, Prescott CA. The temporal relationship of the onsets of alcohol dependence and major depression: using a genetically informative study design. Psychol Med 2006; 36:1153-62.
40. Fergusson DM, Boden JM, Horwood LJ. Alcohol misuse and psychosocial outcomes in young adulthood: results from a longitudinal birth cohort studied to age 30. Drug Alcohol Depend 2013; 133:513-9.

41. Brown S, Inaba R, Gillin J, Schuckit M, Stewart M, Irwin M. Alcoholism and affective disorder: clinical course of depressive symptoms. Am J Psychiatry 1995; 152:45-52.

42. Tao S, Wu X, Zhang Y, Zhang S, Tong S, Tao F. Effects of sleep quality on the association between problematic mobile phone use and mental health symptoms in Chinese college students. Int J Environ Res Public Health 2017; 14:185.

43. Wu X, Tao S, Zhang Y, Zhang S, Tao F. Low physical activity and high screen time can increase the risks of mental health problems and poor sleep quality among Chinese college students. PLoS One 2015; 10:e0119607.

44. Feng Q, Zhang Q, Du Y, Ye Y, He Q. Associations of physical activity, screen time with depression, anxiety and sleep quality among Chinese college freshmen. PLoS One 2014; 9:e100914.

45. Teychenne M, Ball K, Salmon J. Sedentary behavior and depression among adults: a review. Int J Behav Med 2010; 17:246-54.

46. Halperin AC, Smith SS, Heiligenstein E, Brown D, Fleming MF. Cigarette smoking and associated health risks among students at five universities. Nicotine Tob Res 2010; 12:96-104.

47. McChargue DE, Spring B, Cook JW, Neumann CA. Reinforcement expectations explain the relationship between depressive history and smoking status in college students. Addict Behav 2004; 29:991-4.

48. Paperwalla KN, Levin TT, Weiner J, Saravay SM. Smoking and depression. Med Clin North Am 2004; 88:1483-94.

49. Lee G, Han K, Kim H. Risk of mental health problems in adolescents skipping meals: the Korean National Health and Nutrition Examination Survey 2010 to 2012. Nurs Outlook 2017; 65:411-9.

50. Mohan J, Xiaofan G, Yingxian S. Association between sleep time and depression: a crosssectional study from countries in rural Northeastern China. J Int Med Res 2017; 45:984-92.

51. Lemola S, Perkinson-Gloor N, Brand S, Dewald-Kaufmann JF, Grob A. Adolescents' electronic media use at night, sleep disturbance, and depressive symptoms in the smartphone age. J Youth Adolesc 2015; 44:405-18.

52. Müller MR, Guimarães SS. Impacto dos transtornos do sono sobre o funcionamento diário e a qualidade de vida. Estud Psicol (Campinas) 2007; 24:519-28

53. Ye Y, Wang P, Qu G, Yuan S, Phongsavan P, He Q. Associations between multiple health risk behaviors and mental health among Chinese college students. Psychol Health Med 2016; 21:377-85. 
54. Instituto Brasileiro de Geografia e Estatística. Pesquisa Nacional de Saúde 2013. Percepção do estado de saúde, estilos de vida e doenças crônicas. Brasil, Grandes Regiões e Unidades da Federação. https://bvsms.saude.gov.br/bvs/ publicacoes/pesquisa_nacional_saude_2013_ estado_saude_vida_doencas_cronicas.pdf (accessed on 10/Oct/2017).

55. Ströhle A, Höfler M, Pfister H, Müller A-G, Hoyer J, Wittchen $\mathrm{H}-\mathrm{U}$, et al. Physical activity and prevalence and incidence of mental disorders in adolescents and young adults. Psychol Med 2007; 37:1657-66.

56. Goodwin RD. Association between physical activity and mental disorders among adults in the United States. Prev Med 2003; 36:698-703.

57. Rimer J, Dwan K, Lawlor DA, Greig CA, McMurdo M, Morley W, et al. Exercise for depression. Cochrane Database Syst Rev 2012; (7):CD004366

58. Cecil J, McHale C, Hart J, Laidlaw A. Behaviour and burnout in medical students. Med Educ Online 2014; 19:25209.
59. Elliot CA, Kennedy C, Morgan G, Anderson SK, Morris D. Undergraduate physical activity and and depressive symptoms: a national study. Am J Health Behav 2012; 36:230-41.

60. Kalmbach DA, Arnedt JT, Song PX, Guille C, Sen S. Sleep disturbance and short sleep as risk factors for depression and perceived medical errors in first-year residents. Sleep 2017; 40:zsw073.

61. Firth J, Solmi M, Wootton RE, Vancampfort D, Schuch FB, Hoare E, et al. A meta-review of "lifestyle psychiatry": the role of exercise, smoking, diet and sleep in the prevention and treatment of mental disorders. World Psychiatry 2020; 19:360-80.

62. Li L, Wu C, Gan Y, Qu X, Lu Z. Insomnia and the risk of depression: a meta-analysis of prospective cohort studies. BMC Psychiatry 2016; 16:375. 


\section{Resumo}

O estudo buscou examinar a associação entre comportamentos relacionados ao estilo de vida e sintomas depressivos em estudantes universitários. O estudo transversal analisou os dados da linha de base de um estudo em estilo coorte dinâmica de uma universidade pública da Região Centro-oeste do Brasil, recrutados em 21 cursos de graduação de tempo integral. Foram incluídos no estudo, universitários de até 25 anos de idade matriculados pela primeira vez na universidade, exceto mulheres gestantes e lactantes. Todos os universitários que atenderam os critérios de elegibilidade foram convidados a participar do estudo. Entre o total de 1.212 elegíveis, 1.038 foram estudados (85,6\%). Todos os participantes responderam a um questionário auto-aplicado sobre tabagismo, consumo de álcool, tempo de uso de computador, Internet e TV, duração do sono e padrões alimentares. Os sintomas depressivos foram avaliados com o Patient Health Questionnaire-9 (PHQ-9). Modelos de regressão Poisson multivariada, estratificados por sexo, foram usados para estimar as associações. Sintomas depressivos foram observados em 31,6\% da amostra (homens, 23,6\%; mulheres, 39,9\%; valor de $p$ do teste de qui-quadrado =0,01). Tabagismo, consumo de bebidas destiladas e hábitos alimentares irregulares mostraram associação direta com sintomas depressivos em homens e mulheres. A ocorrência simultânea de dois comportamentos de risco (homens: $R P a=2,23$, IC95\%: 1,25; 3,99; mulheres: $R P a=1,54, I C 95 \%: 1,03 ; 2,30)$ e três ou mais comportamentos de risco (homens: $R P a$ = 3,42, IC95\%: 1,90; 6,16; mulheres: $R P a=2,09$, IC95\%: 1,39; 3,15) aumentaram a ocorrência de sintomas depressivos entre os universitários. Comportamentos não saudáveis relacionados ao estilo de vida mostraram uma associação com o aumento de sintomas depressivos entre os universitários. Os achados sugerem a necessidade de intervenções para incentivar mudanças de estilo de vida, no sentido de promover a saúde mental e melhorar a qualidade de vida desse grupo.

Transtorno Depressivo; Estudantes;

Universidades; Estilo de Vida; Epidemiologia

\section{Resumen}

El objetivo de este estudio fue examinar la asociación entre los comportamientos relacionados con el estilo de vida y síntomas depresivos entre estudiantes universitarios. Este estudio transversal analizó datos de referencia de un estudio de cohorte dinámica, procedentes de una universidad pública en la Región Centro Oeste de Brasil, en los 21 cursos universitarios a tiempo completo. Se incluyeron en el estudio a estudiantes de hasta los 25 años de edad, que estaban inscritos por primera vez en la universidad, excepto mujeres embarazadas y/o mujeres lactantes. Todos los estudiantes que cumplieron con los criterios de eligilidad fueron invitados a participar en el estudio. De un total de 1.212 estudiantes elegibles, fueron estudiados 1.038 (85,6\%). Todos los participantes respondieron a un cuestionario autoadministrado sobre tabaco, consumo de bebidas destiladas, tiempo ante la pantalla, duración del sueño, así como patrones de comidas. Los sintomas depresivos se evaluaron usando el Patient Health Questionnaire-9 (PHQ-9). También se utilizaron modelos de regresión de Poisson multivariados estratificados por sexo para estimar las asociaciones. Se observaron sintomas depresivos en un 31,6\% (hombres 23,6\%; mujeres 39,9\%; valor de p test de chicuadrado $=0,01$ ) de los estudiantes. Fumar, beber bebidas alcohólicas, y tener hábitos irregulares de comidas estuvieron directamente asociados con sintomas depresivos, tanto en hombres, como en mujeres. La co-ocurrencia de dos comportamientos de riesgo (hombres: $a P R=2,23$, IC95\%: 1,25; 3,99; mujeres: $a P R=1,54$, IC95\%: 1,03; 2,30) y tres o más comportamientos de riesgo (hombres: aPR = 3,42, IC95\%: 1,90; 6, 16; mujeres: $a P R=2,09$, IC95\%: 1,39; 3,15) incrementaron la ocurrencia de sintomas depresivos entre los estudiantes. El estilo de vida, relacionado con comportamientos poco saludables, estuvo asociado con un incremento en la ocurrencia de sintomas depresivos entre estudiantes universitarios. Estos resultados sugieren la necesidad de intervenciones animando cambios en el estilo de vida para promover la salud mental y para mejorar la calidad de vida de este grupo.

Trastorno Depresivo; Estudiantes; Universidades; Estilo de Vida; Epidemiología
Submitted on $10 / \mathrm{Jul} / 2020$

Final version resubmitted on 17/Dez/2020

Approved on 08/Jan/2021 